\title{
Dynamic model: The influence of project management competencies, resources and capabilities towards the performance of small-medium qualification contractor in Indonesia
}

\author{
Miftahul Huda. \\ Civil Engineering Program, Engineering Faculty, \\ University of Wijaya Kusuma Surabaya, Indonesia \\ Email ; huda.uwks@gmail.com
}

\begin{abstract}
The previous researchers have proven that there is a positive and significant influence between the project management competency and corporation's resource or capability towards the performance using the static model. The purpose of this research is to develop the model and to simulate the relationship among project management competency, resource and capability, and the performance of small-medium qualification contractor in Indonesia using the dynamic model. There are four steps used in this research, developing the conceptual model, collecting the data through questionnaire and interview, developing the causal pie chart, developing the flow chart, simulating and analyzing the developing result. The research result shows that, through the development of dynamic model, the project management competency and corporation's resource and capability in particular time frame can influence the performance of small-medium qualification contractor significantly.
\end{abstract}

Keywords : competence, performance, resource, small-medium contractor, dynamic system.

\section{INTRODUCTION}

The categorization of contractor in Indonesia is based on the criteria such the competency's level or depth and the potential effort, and also the capability of doing the implementation of its job's construction based on the risk and/or the technology usage and/or the cost value criteria (LPJKN, 2013)[1]. In 2014, the number of contractors in Indonesia reached 141,665 corporations, those consist of small qualification (S) 126.467 (89,27\%), medium qualification (M) 14.155 (9,99\%) and big qualification (B) 1.043 (0,74\%) (LPJKN, 2014)[2]. The amounts of big qualification only could reach $0,74 \%$ with the marketing segments for almost $85 \%$, and the rest $15 \%$ was handed by small-medium qualification (Gapensi, 2012)[3]. The marketing segments handed by those small-medium qualification are not equivalent with the number of existing corporations. This condition might cause the competitions between the others become unhealthy and distorted (Husaini, 2013)[4]. As a consequence, a lot of small-medium qualification are not able to continue their corporations, moreover, there are many more which do not operate again. (Ervianto, 2007) [5]. Therefore, they need an effort and policy from the contractor stake holders so that it might increase the performance.

Typically, the small-medium qualification contractors in Indonesia are in poor condition. They have a very low management competence, inefficient management system, limited resources and capability, and limited human resources (Wheelen \& Hunger, 2005)[6]. The insufficient things of those small-medium qualification contractors in Indonesia are the delaying schedule, the fixing in finishing step, the broken materials in location, waiting for the fixing equipment and tools which have not come yet. Some of those insufficient things are caused by a lot of changes in planning, the low-skilled workers, the delaying in decision making, bad coordination, the weakness of planning and controlling, the delaying in materials delivery and inappropriate working methods (Abduh, 2008)[7]. The high risky problems towards the decreasing performance of contractors, especially the small-medium qualification contractors are caused by internal factor, there are management quality and human resource (Sudarto, 2007)[8]. In line with Waluyo's explanation (2014)[9], that $85 \%$ of management problems is in the using system, while $15 \%$ is in the human resource. One of the important factors to increase resource, capability, strategic decision and performance, is through developing the project management competency (Isik et al., 2010)[10], it can be a training or competency certification. 
Project Management Body of Knowledge (PMBOK $\left.{ }^{5 \text { th }}\right)[11]$ is one of the international standardizations in project managing that was made by Project Management Institute (PMI). According to PMBOK ${ }^{5 \text { th }}$ (2012), project management is the application of knowledge, skills, tools and techniques in project activities to fulfill the project needs (PMBOK ${ }^{\text {th }}, 2012$ ), including the document which describes the norms, methods, process and implementation as the important element from project management professional scope. PMBOK purposes to identify the good work and to determine the general steps in project managing (Rehacek, 2014)[12]. PMBOK standard is identical with standard project management competency in relevant with the implementation of knowledge, skills, tools and techniques that are needed to hand other projects (Wibowo, 2011)[13], it begins with planning, implementing, controlling and coordinating during the project implementation, to keep the project's duration, quality and cost appropriate with the previous plan (Ervianto, 2007; Husen, 2009)[5] [14]. The scope of project management $\left(\mathrm{PMBOK}^{5 \text { th }}, 2008\right)$ is one of the documents which explains some knowledge in the area of project management. There are 9 knowledge area in project management, those are scope management, time management, cost management, human resource management, risk management, communication management, quality management, supplying management and project integration management. Some supporting arguments in the knowledge area based on the contractor competency are Isik et al.( 2010)[10], explaining that project management competency is a part of contractor's resource and capability. The strong and supported project management competency will support the quality of strategic decision in contractor corporation (Dietrich \& Lehtonen 2005 ; Asmarani, 2006 ; Arrto et al., 2007)[15] [16] [17] and it will develop the corporation performance (Absah, 2008 ; Huda, 2009 ; Isik et al., 2010; Ardiana et al., 2011)[18] [19] [10] [20].

The contractors' success in developing the performance is very relevant with the capability and resource. The resource and capability might include the tangible assets and intangible assets (Pearce \& Robinson, 2003 dan Cheah \& Miller, 2004) [21] [22]. The contractor corporations, especially in small-medium qualification, have limited tangible assets because of this characteristic, including the project maximum limit which is allowed to be done (Permen PU Nomor 08/PRT/M/2011; LPJKN, 2008)[23]. Particularly, the resources limitations in small-medium constructors are about the human resources' number and quality, constructions equipment, technology capability, good financial capability and accessibility, thus they need a very well cooperation or collaboration with a big constructor (Abduh, 2008) [6]. Based on the Construction Service Development Board (LPJKN) data, the certificated professional workers in constructional sectors are 48.761 people or $7,17 \%$ from the total amount, meanwhile the certificated and skilled workers are 109.723 people or 5,38\% from the total amount of skilled workers (Dardak, 2014)[24].

Nowadays, contractor corporations are still facing the condition where the qualified human resources are limited. The number of certificated workers who work in contractor corporation are 996.897 certifications, with 17.822 professional certifications and 439.075 skilled certifications. Those numbers only reach $22 \%$ of the total workers in constructions which are 6,3 million workers. According to the statistic calculating in LPJKN (2014)[2], it has been known that there are some professional worker qualifications, (5\%) beginners, (69\%) youth, (24\%) medium, and (2\%) prominence. These show that the lack of professional composition based on the professional qualification hierarchy. Meanwhile, the skilled compositions are level I qualification (40\%), level II qualification (36\%), level III (10\%) and professional-skilled (15\%). Many profession associations which are lack of competence and inappropriate with the procedure give the professional and skilled certificate for their members. It can be seen from the explanation above that, in fact, the resources and capability of small-medium constructors especially about human resources are still low, whether the quality or quantity. Yet, in Sudarto's opinion (2007)[7], the corporations' resources can improve the corporations' performance. A corporation must have particular resources to gain the highest performance achievement (Absah, 2008) [18].

A number of constructor with the small-medium qualification in Indonesia are so many, they spread all over this country and their existences are rather strategic in gaining the national workers in order to make Masterplan for Acceleration and Expansion of Indonesia's Economic Development (MP3EI), thus, the smallmedium constructors need to gain the attention from others. This research develops the static model which has been done before by ; Isik et al., 2010; Ardiana, 2011; Wibowo, 2011; Huda \&Wibowo, 2013)[10] [20] [25] by using dynamic model, to analyze the influence of project management construction and resources/capability in corporation towards the workers' performance in Indonesia. The used dynamic model, hopefully, more beneficial for the contractors while they are making the policy to evaluate their performance, especially the capability of project management competency and resources. 


\section{A. Conceptual model}

\section{RESEARCH MODEL}

Some theories and previous studies are becoming the basic of this research conceptual model, those are Absah (2008)[18], Isiket al. (2010)[10] dan Huda \& Wibowo (2013) [25]. The research of Absah (2008)[18] showed that, the competence of corporation gives a strong influence to the performance and competitiveness, also the performance comes from particular resources and competence. Meanwhile, the research from Isiket al., (2010)[10] dan Huda \& Wibowo (2013)[25] concludes that (a) project management competence has a big deal in corporations' resources and capability, (b) project management competence has a significant influence towards corporation's performance, (c) Resource and performance have a significant influence towards the corporation's performance. Based on the former researches, the conceptual model has been drawn as in Figure 1. This conceptual model has 3 variables, two of them are exogenous variables, including Project Management Competency (PMC) and Performance (P). The rest is endogenous variable, Resources and Capabilities (RC). Conceptual model from relationship of PMC-RC-P can be seen in Figure 1.

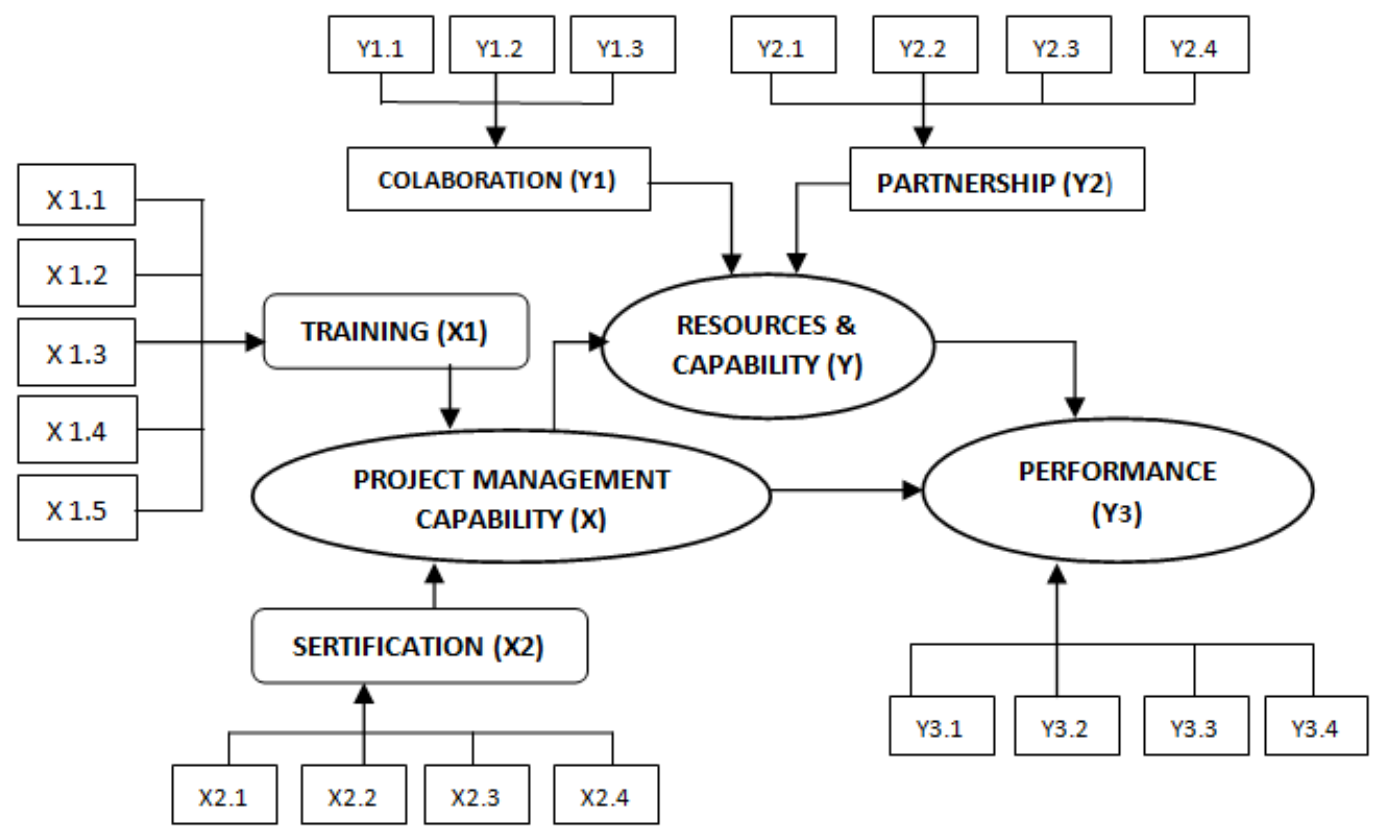

Fig. 1. The Conceptual model from relationship of PMC-RC-P

The mathematical equation can be formulated :

$Y=(Y i n+Y j n+Y k n)+(X m n+X n n)$

Where :

\author{
$\mathrm{X}=$ Project Management \\ Competencies (Training $=\mathrm{Xmn}$ \\ \& Sertification $=\mathbf{X n n})$ \\ 1. Scheduling (X1.1) \\ 2. Cost (X1.2) \\ 3. Human resources (X1.3) \\ 4. Communication (X1.4) \\ 5. Scope of the project (X1.5) \\ 6. Quality (X2.1) \\ 7. Risk (X2.2)
}

\section{$\mathbf{Y}=$ Resources and Capabilities \\ (Collaboration $=$ Yin \& \\ Partnership= Yjn)}

1. Financial resources (Y1.1)

2. Technique competency (Y1.2)

3. Leadership (Y1.3)

4. Experiences (Y2.1)

5. Brands (Y2.2)

6. R\&D capabilities (Y2.3)

7. Innovation capabilities (Y2.4)

\section{Performance perspective} (Ykn) ;

1. Financial (Y3.1)

2. Customer (Y3.2)

3. Process of Internal business (Y3.3)

4. Learning and growthing (Y3.4)

\section{B. Stock flow diagram for PMC-RC-P model}

Stock flow diagram served in the following is based on the causal loop diagram in the previous part. A variable from causal loop diagram is transferred in the stock form, along with the appropriate connection. The variables are chosen according to the relevancy in the stock flow system, and their potency which is influent towards the performance. Figure 2 shows the project management competency (PMC), resources or capability (RC) and performance (P). 


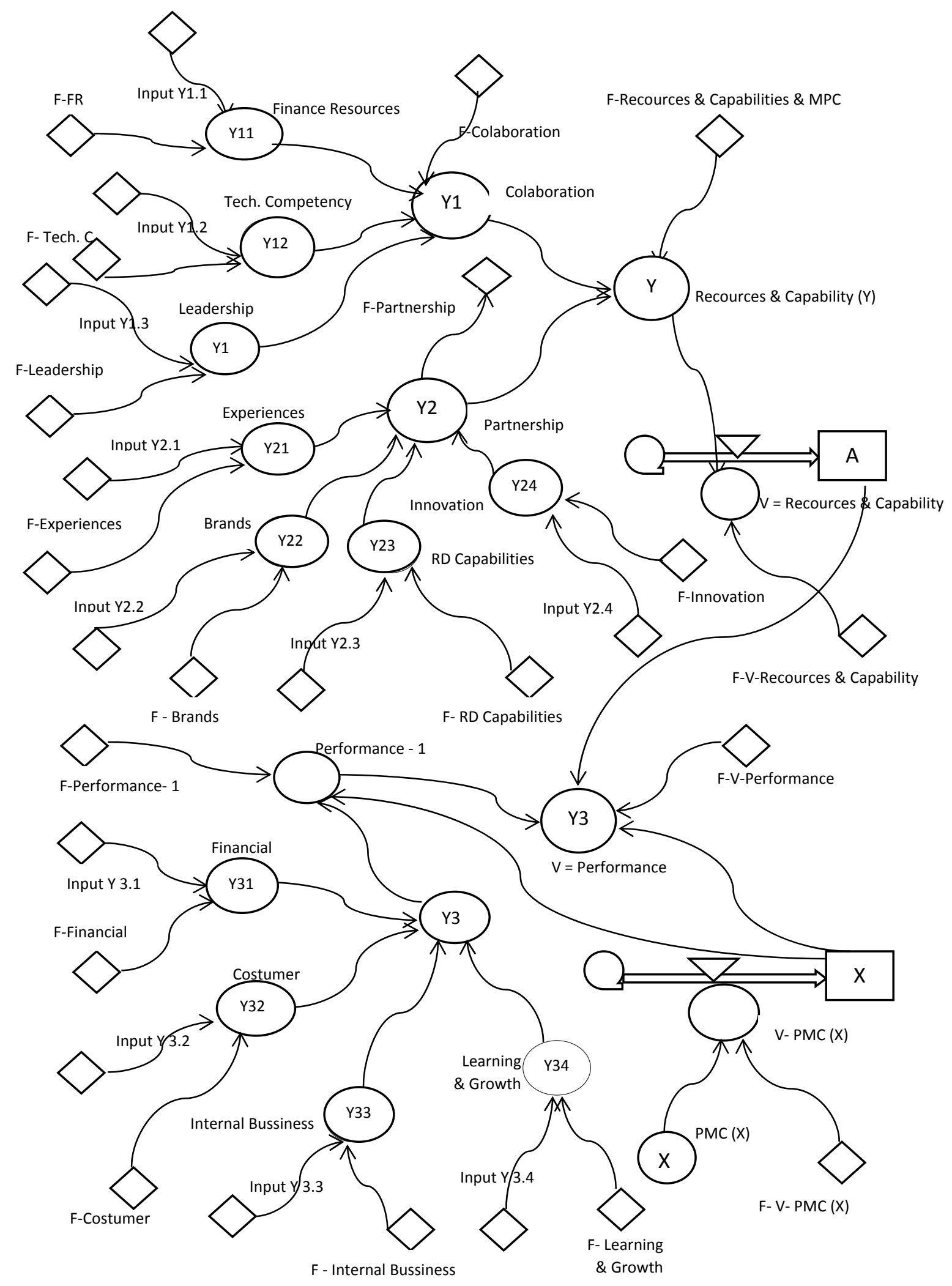

Fig. 2. Stock flow diagram of PMC-RC-P model without scenario (continued) 


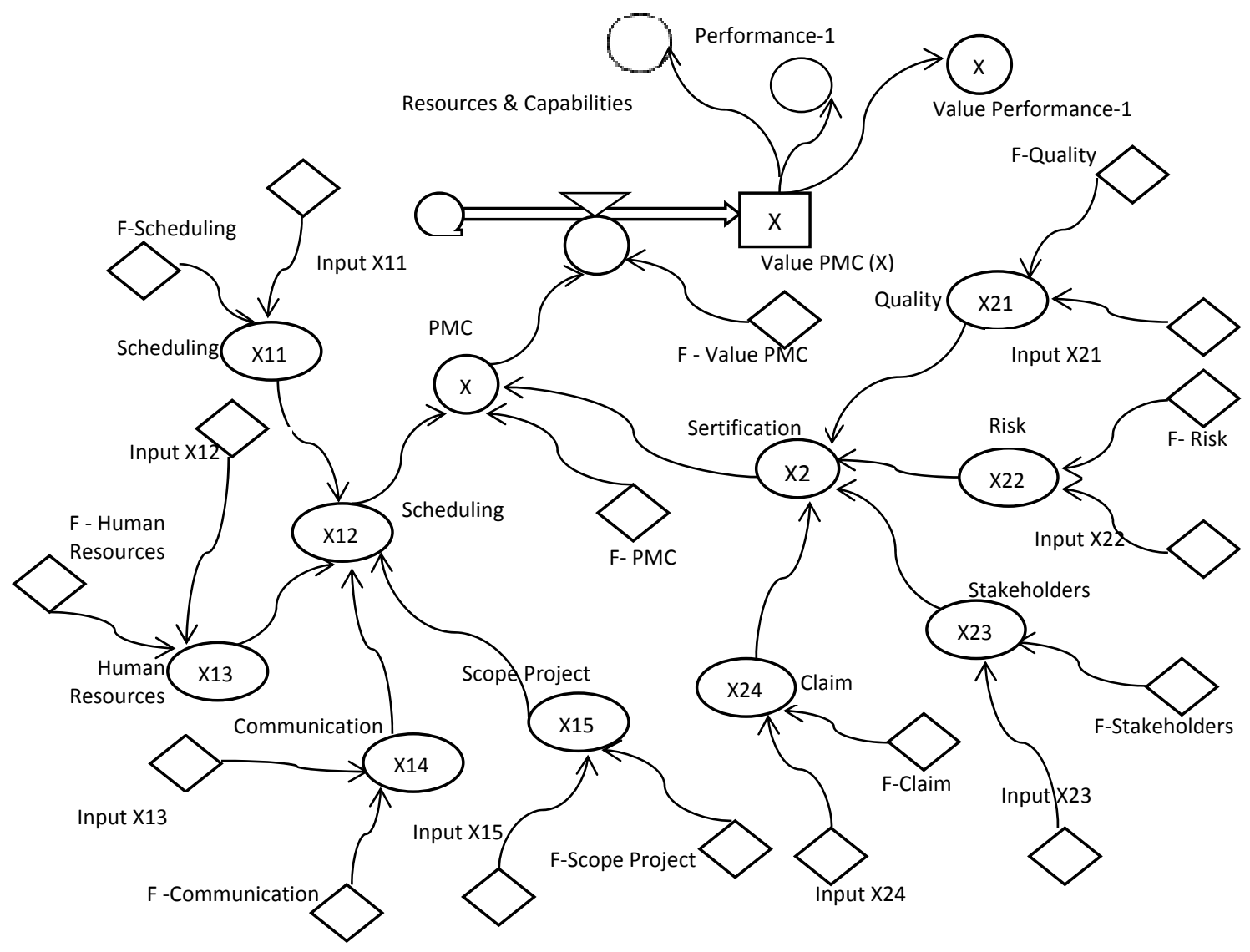

Fig. 2. Stock flow diagram of PMC-RC-P model without scenario (continuing)

\section{Dynamic simulation of PMC-RC-P model.}

Figure 3 shows that the dynamic model of management competency, resources or capabilities and performance consist of 4 sub-systems, those are collaboration and partnership to sum up the training and certification both in professional standard competency and skilled standard competency. Based on the conceptual model of PMC-RC-P, those sub-systems are categorized into 3 variables. A model simulation is a dynamic change and shown both in graphic time and time table. The result from this simulation can be explained in three sub-system, they are project management competency, resources/capabilities and performance.

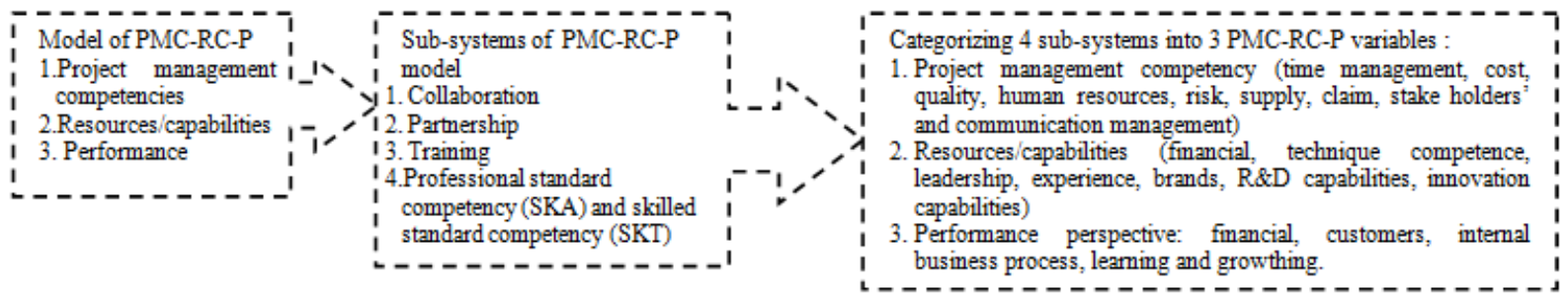

Fig. 3. The system and sub-system of PMC-RC-P dynamic model with scenario.

The early assumption of dynamic model is based on these followings:

1. Training score $(\mathrm{X} 1)=70 \%$ (this score is the percentage of total average from 5 indicator inputs which influence time management, cost management, human resources management, communication management, project scope management)

2. Certification score (X2) $=75 \%$ (this score is the percentage of total average from 4 indicator inputs which influence quality management, risk management, chain supply management, claim management)

3. Collaboration score $(\mathrm{Y} 1)=80 \%$ (this score is the percentage of total average from 3 indicator inputs which influence financial resources, technique competency and leadership) 
4. Partnership score $(\mathrm{Y} 2)=78 \%$ (this score is the percentage of total average from 3 indicator inputs which influence experiences, corporations’ image, R\&D capabilities, innovation capabilities)

5. Initial score of $\mathrm{PMC}=0,725=72,5 \%$

6. Initial score of $\mathrm{RC}=0,768=76,8 \%$

\section{RESULT AND DISCUSSION}

\section{A. The basis of PMC}

Based on the result of simulation model with scenario, it shows that the score of PMC in the early year (0 year) is $0,725(72,5 \%)$ increasing to $0,797(79,7 \%)$ in the tenth year $\left(10^{\text {th }}\right.$ year). The increasing score of PMC influences the performance score (Y3), thus the performance $(\mathrm{P})$ score is also increasing in the early time of simulation year (0 year) for $0,76(76 \%)$ becoming $0,822(82.2 \%)$ in the $10^{\text {th }}$ year (figure 4$)$. In the other hands, PMC score influences the resources and capabilities score as well. The improvement of PMC score is followed by $\mathrm{RC}$ score too, so the RC score in the early simulation time $(0$ year) is $0,768(76.8 \%)$ increasing to 0,846 $(84.6 \%)$ in the $10^{\text {th }}$ year (figure 5$)$. Those results show that PMC gives an influence positively and significantly towards the RC and corporations' performance.

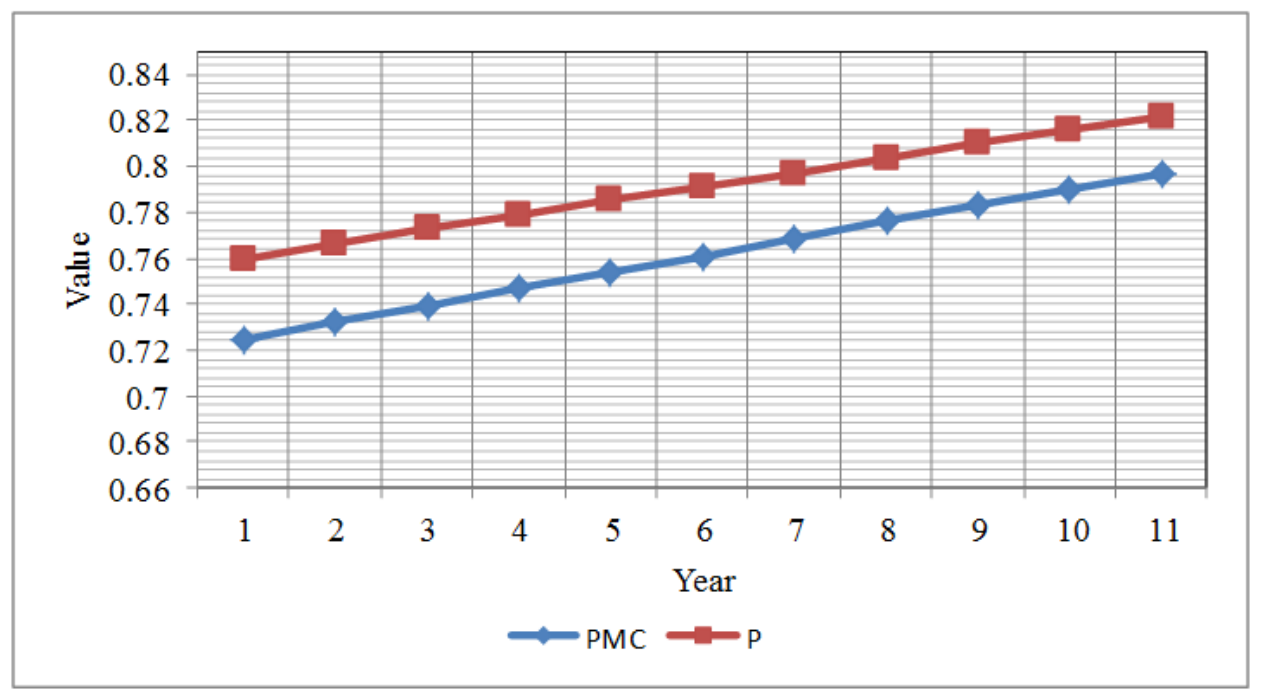

Fig. 4. Relationship among PMC and P

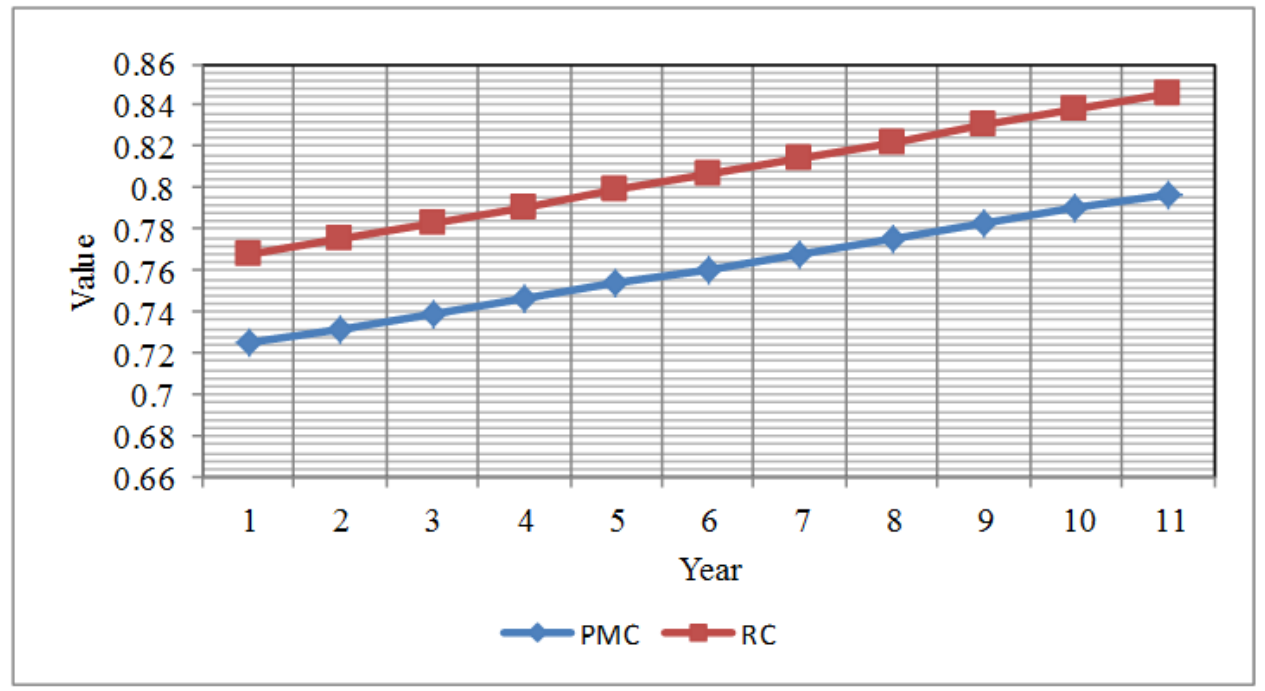

Fig. 5. Relationship among PMC \& RC

To improve the project management competency of small-medium contractors in Indonesia, it needs a training and professional competency certification. A training and professional certification of project management competency is very possible to do by the contractor through structural training that is organized by Construction Service Development Board (LPJK). According to corporations' qualifications and classified working area, the small-medium contractors in Indonesia have their own different characteristics. Yet, the policy in order to develop the project management competency for small-medium contractors in Indonesia might use the model in 
this research, with training and competency certifying. The PMC-RC-P model in this research shows that the project management competency is the most important aspect for small-medium contractors in Indonesia, because the project management competency can give an influence towards RC (Isik et al., 2010), strategy and performance improvement in contractor corporations (figure 4 and 5). The result of simulation model shows that the small corporations, generally, have a project management competency in a low/medium level, low level in quality management, claim management, and risk management. Meanwhile, the medium corporations, generally, have a good project management competency, very well in time management, quality management, risk management and communication management (Huda \& Wibowo, 2013).

It needs more attention and notice from all sides to develop the project management competency of smallmedium contractors in Indonesia through the relevant curriculum of higher education, professional competence certification in the project management area and the training from profession/corporation associations. Indonesia should need the standard form of project management competency nationally, and for preparing the competition in project managerial construction competency in the near future. University and Academician shall do the acceptable curriculum that suits to the needed competences in each field with inputting the minimum 9 areas of project management competency fitting with the indicators and this research (PMBOK $\left.{ }^{4 \text { th }}\right)$.

\section{B. The basis of Resources and Capabilities}

Based on the model simulation, it shows that the score of resources and capabilities (RC) in the early simulation year (0 year) is $0,768(76,8 \%)$ increasing to $0,846(84,6 \%)$ in the $10^{\text {th }}$ year. Along with the increasing score of RC, the performance score (P3) is increasing gas well, so the performance score in the early simulation year (0 year) is $0,76(76 \%)$ increasing to $(82.2 \%)$ in the $10^{\text {th }}$ year (figure 6 and table 1$)$. This result shows that resources and capabilities from the corporations has a positive and significant influence towards the corporations' performance.

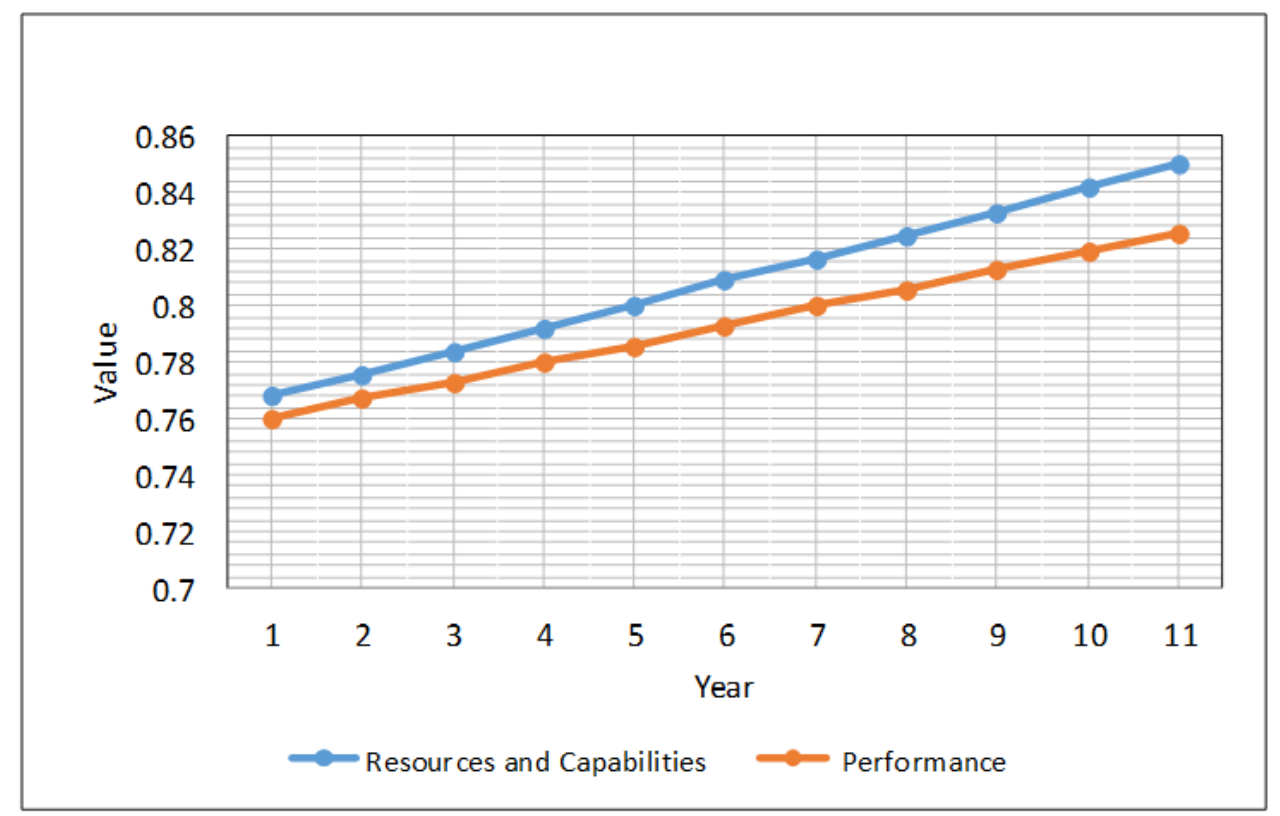

Fig. 6. Relationship among RC \& P

Table 1 Value RC \& P in the $10^{\text {th }}$ year

\begin{tabular}{|c|c|c|}
\hline Years & Value Resource \& Capabilities (Y) & Value Performance (Y3) \\
\hline 0 & 0.768 & 0.760 \\
\hline 1 & 0.776 & 0.767 \\
\hline 2 & 0.784 & 0.773 \\
\hline 3 & 0.792 & 0.780 \\
\hline 4 & 0.800 & 0.786 \\
\hline 5 & 0.809 & 0.793 \\
\hline 6 & 0.817 & 0.800 \\
\hline 7 & 0.825 & 0.806 \\
\hline 8 & 0.833 & 0.813 \\
\hline 9 & 0.842 & 0.819 \\
\hline 10 & 0.850 & 0.826 \\
\hline
\end{tabular}


The PMC-RC-P model in this research shows that the resources and capabilities in small-medium contractor can be both improved through project management competency, and through partnership or collaboration with other corporations (figure 6). The partnership of small-medium contractors is a mutualism partnership with big corporations along with the training and development from the big corporations. The partnership will produce the efficient and synergic resources among those partners, thus it might increase the image of small-medium corporations, apply the result of this research, adopt the constructor innovations from the big contractors. The collaboration term is usually taken to explain the practices between two sides or more to achieve the same purposes and involve both each work and collective work in gaining the same purposes. The main motivation is to gain the collective results that are very impossible to gain with the individual work. Besides the cooperation, those corporations collaborate in gaining the innovative results and new idea. Resources and capabilities in tangible or intangible assets are one of the important parameters for small-medium contractors in Indonesia, because the resources or capabilities can influence the contractors' performance (Pearce \& Robinson, 2003 and Cheah\& Miller, 2004) [21] [22]. Typically, the contractors in small qualification have a low/medium resources or capabilities, while the medium contractors have a medium/good resources or capabilities, good in both leadership and experience (Huda \& Wibowo, 2013).

\section{The basis of Performance $(P)$}

Based on the result of model simulation, it shows that project management competency (PMC) score increases in the early simulation year (0 year) from $0,725(72,5 \%)$ becoming $0,797(79,7 \%)$ in the $10^{\text {th }}$ year. The same case is happened to the resources and capabilities (RC), in the early simulation year (0 year), it starts with $0,768(76,8 \%)$ increasing to $0,846(84,6 \%)$ in the $10^{\text {th }}$ year. The influence of PMC score and RC score is in the performance improvement (Y3), in the early simulation year (0 year) it starts with 0,76 (76 \%) then increasing to $0,822(82.2 \%)$ in the $10^{\text {th }}$ year (figure 7 and table 2 ).

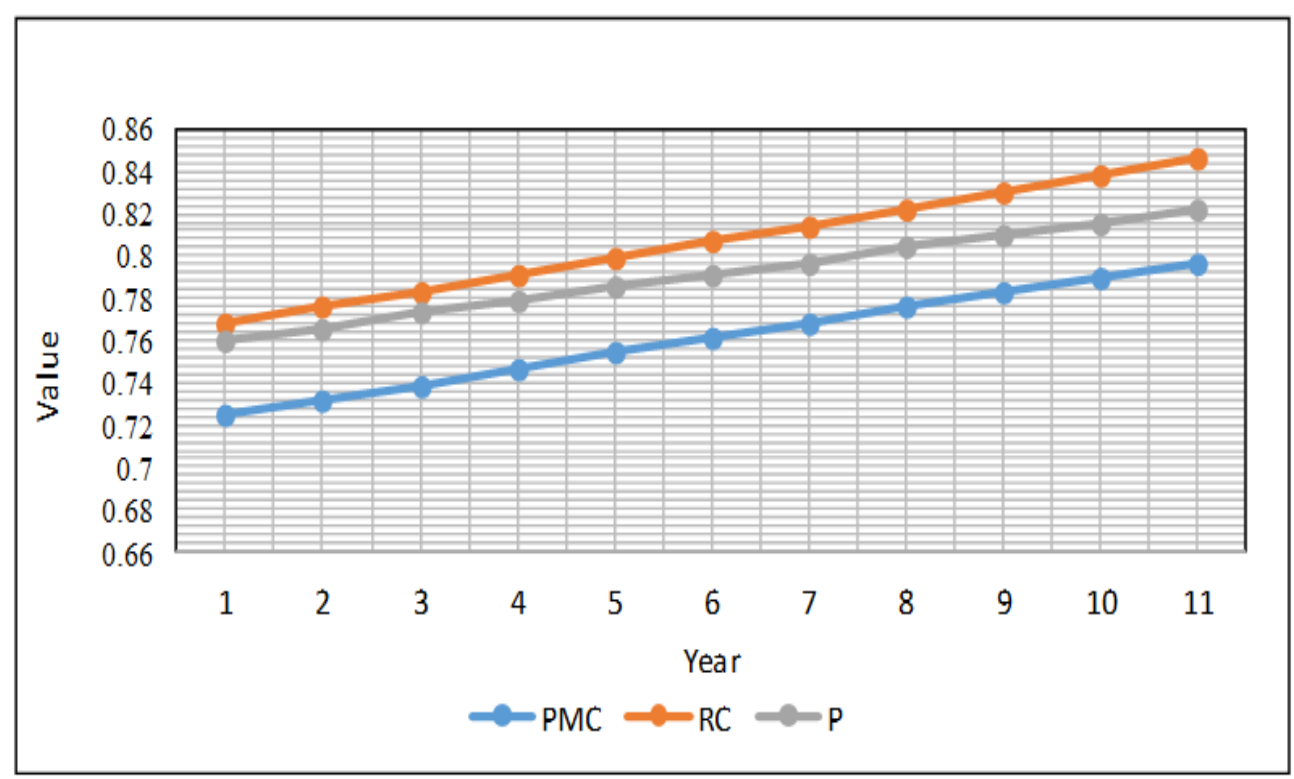

Fig. 7. Relationship among PMC. RC and P.

Table 2 Value PMC, RC \& P in the $10^{\text {th }}$ year

\begin{tabular}{|c|c|c|c|}
\hline Years & Value PMC & Value RC (Y) & Value P (Y3) \\
\hline 0 & 0.725 & 0.768 & 0.760 \\
\hline 1 & 0.732 & 0.776 & 0.766 \\
\hline 2 & 0.739 & 0.783 & 0.773 \\
\hline 3 & 0.747 & 0.791 & 0.779 \\
\hline 4 & 0.754 & 0.799 & 0.785 \\
\hline 5 & 0.761 & 0.807 & 0.791 \\
\hline 6 & 0.768 & 0.814 & 0.797 \\
\hline 7 & 0.776 & 0.822 & 0.804 \\
\hline 8 & 0.783 & 0.830 & 0.810 \\
\hline 9 & 0.790 & 0.838 & 0.816 \\
\hline 10 & 0.797 & 0.846 & 0.822 \\
\hline
\end{tabular}




\section{Policy scenario}

The policy scenario is assumed with giving the first assumption score of PMC through the first average percentage of training and certification. Meanwhile, the first score of RC is assumed through the first average scenario percentage of collaboration and partnership. The scenario of policy model is created in three scenarios as it is described in table 3 .

Table 3. The scenario of policy model PMC-RC-P

\begin{tabular}{|l|l|l|l|}
\hline \multicolumn{1}{|c|}{ Scenario (s) } & first & Second & Third \\
\hline The average score of training percentage & Increased by 1\% & Increased by 3\% & Increased by 5\% \\
\hline The average score of certification percentage & Increased by 2\% & Increased by 3\% & Increased by 5\% \\
\hline The average score of collaboration percentage & Increased by 2\% & Increased by 3\% & Increased by 6\% \\
\hline The average score of partnership percentage & Increased by 1\% & Increased by 3\%) & Increased by 6\% \\
\hline
\end{tabular}

According to the simulation models with some scenarios, they show the best result in third scenario. The project management competency score in third scenario is improving a lot in the early simulation year (0 year) from $0,725(72,5 \%)$ to $0,802(80.2 \%)$ in the $10^{\text {th }}$ year. It also followed by the increasing score of resources and capabilities from $0,76(76 \%)$ in the early simulation year ( 0 year) to $0,826(82.6 \%)$ in the $10^{\text {th }}$ year. The PMCRC-P model in stock flow diagram with third scenario and the comparison from first, second and third scenario can be seen in figure 8 also in table 4 .

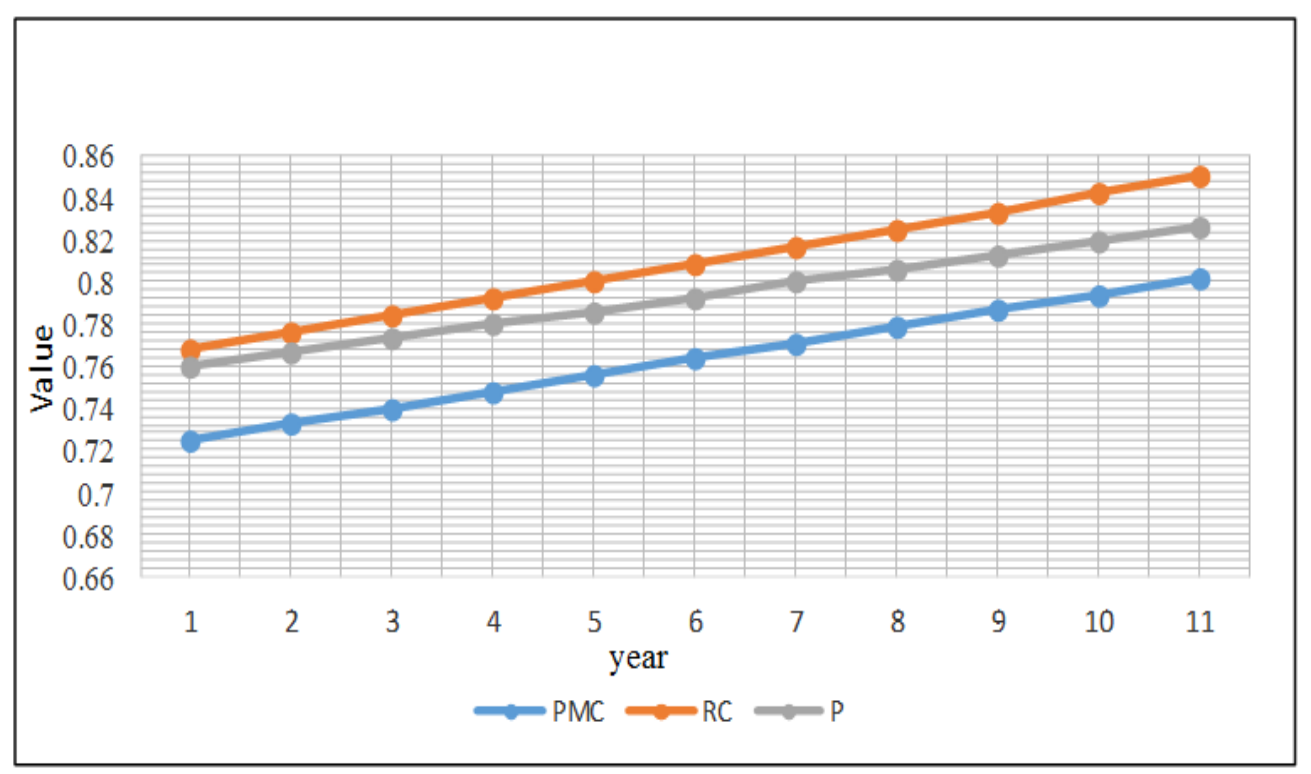

Figure 8. Relationship among PMC, RC and P with first,second and third scenario

Table 4 Value of PMC, RC and P in the $10^{\text {th }}$ Year With Third Scenario

\begin{tabular}{|c|c|c|c|}
\hline Years & Value PMC (X) Scenario 3 & Value RC (Y) Scenario 3 & Value P (Y3) Scenario 3 \\
\hline 0 & 0.725 & 0.768 & 0.760 \\
\hline 1 & 0.733 & 0.776 & 0.767 \\
\hline 2 & 0.740 & 0.784 & 0.773 \\
\hline 3 & 0.748 & 0.792 & 0.780 \\
\hline 4 & 0.756 & 0.800 & 0.786 \\
\hline 5 & 0.764 & 0.809 & 0.793 \\
\hline 6 & 0.771 & 0.817 & 0.800 \\
\hline 7 & 0.779 & 0.825 & 0.806 \\
\hline 8 & 0.787 & 0.833 & 0.813 \\
\hline 9 & 0.794 & 0.842 & 0.819 \\
\hline 10 & 0.802 & 0.850 & 0.826 \\
\hline
\end{tabular}




\section{CONCLUSION}

The use of dynamic simulation tool is a model diagram illustrating a causal loop, stocks and flows that are intended to show the relationship of different variables and how these variables affect each other. In this study the influence of variables modeled in the form of an increase in the value of a variable percentage of the development time. Results of simulation modeling can be done by giving the value of the different variables and the development of the future. The model suggested in this study shows the relationship between the project management competence (PMC), resource / capability (RC) and performance (P) that can provide the most optimal improvement.

\section{REFERENCES}

[1] Lembaga Pengembangan Jasa Konsuksi Nasional (LPJKN), Peraturan Lembaga Pengembangan Jasa Konstruksi Nasional, Nomor 6, Tahun 2013, Perubahan Kedua Atas Peraturan Lembaga Pengembangan Jasa Konstruksi Nasional Nomor 04, Tahun 2011 Tentang Tatacara Registrasi Ulang, Perpanjangan Masa Berlaku Dan Permohonan Baru Sertifikat Tenaga Kerja Ahli Konstruksi. Jakarta, 2013.

[2] Lembaga Pengembangan Jasa Konsuksi Nasional (LPJKN),, Badan Usaha Jasa Konstruksi Berdasarkan Kualifikasi di Indonesia. http://www. lpjk.net/statistik-1-badan-usaha-lpjk.html (diakses, 9 Desember 2014, pukul 16,45). 2014.

[3] Gabungan Pelaksana Konstruksi Seluruh Indonesia (GAPENSI), Perbandingan Pangsa Pasar (Market Share)Kontraktor Kecil, Menengah dan Besar, Diakses 22 Agustus 2013, http://www. Surat ijin usaha jasa konstruksi.com/gapensi.html (diakses 10 Februari 2013, jam 10.23). 2012.

[4] Husaini, H. W. Hadapi Persaingan Global, Kontraktor Diminta Ikuti Aturan. http://mdn.biz.id/ n/68872/, diakses pada 10 Maret 2014, jam ; 14,35. 2013.

[5] Ervianto, W.I., Manajemen Proyek Konstruksi, Penerbit Andi, Jogyakarta, 2007.

[6] Wheelen, T.L. and Hunger, D.J., Strategic Management and Business Policy, Seventh Edition, Prentice Hall International, Inc., New Jersey, 2005.

[7] Abduh, M., Praktek Perencanaan dan Pengendalian Proyek pada Kontraktor Kecil, ITB., Bandung, 2008.

[8] SudartoIdentifikasi Permasalahan pada Faktor Internal yang Mempengaruhi Kinerja Perusahaan Jasa Konstruksi di Indonesia, Jurnal Teknologi, Edisi No. 2, Tahun XXI (Juni), pp. 102-110. . 2007.

[9] Waluyo,R. Model Hubungan Antara Culture Knowledge Management dan Performance di Perusahaan Konstruksi. Disertasi Program Doktor (S-3) Teknik Sipil, Fakultas Teknik, Universitas Diponegoro Semarang, 2014..

[10] Isik Z. Arditi, David. Irem Dikmen. and M. Talat Birgonul.,Impact of Resources and Strategies on Construction Company Performance, Journal of Management in Engineering, Vol. 26, No.1,pp. 9-18. 2010

[11] PMBOK $^{4 \text { th }}$. A Guide to the Project Management Body of Knowledge. Project Management Institute (PMI), Inc. Four Campus Boulevard Newtown Square, Pennsylvania 19073-3299, USA. 2008,

[12] Rehacek, Petr. Standards ISO 21500 and PMBoK Guide for Project Management.International Journal of Engineering Science and Innovative Technology (IJESIT).Vol. 3, No. 1, pp. 288-295, 2014..

[13] Wibowo, K. 2011,Faktor-Faktor Strategi Pengembangan Daya Saing Kontraktor Indonesia, Disertasi, Program Doktor Teknik Sipil (S3). Universitas Diponegoro Semarang.

[14] Husen, Abrar. Manajemen Proyek ;Perencanaan Penjadwalan dan Pengendalian Proyek.:PenerbitAndi, Yogyakarta, 2009..

[15] Dietrich,P., and Lehtonen, P. Successful managementof strategic intentions through multiple projects -Reflections from empirical study.International Journal of Project Management,Vol.23,No. 4, pp.386-391. 2005.

[16] Asmarani, D.E. Analisis Pengaruh Perencanaan Strategis terhadap Kinerja Perusahaan dalam Upaya Menciptakan Keunggulan Bersaing, Tesis, Universitas Diponegoro, Semarang, 2006.

[17] ArttoK.,Kujala J.,Dietrich P.,Martinsuo M. What is project strategy?, European Academy of Management (EURAM)2007,7 ${ }^{\text {th }}$ Annual Conference, May16-9,Paris,France, 2007.

[18] Absah, Yani. Kompetensi: Sumber Daya Pendorong Keunggulan Bersaing Perusahaan. Jurnal Manajemen Bisnis.Vol. 1, No. 3,pp. 109-116, 2008.

[19] Huda, M., Agung, M.A. Strategies, Performance, Sustainability and Competitiveness Model: Small and Medium Construction Services Industries in Indonesia. World Applied Sciences Journal, Vol. 25, No.8, pp. 1186-1196, 2013

[20] Ardiana, I.D.K. I.A. Brahmayanti, dan Subaedi, Kompetensi SDM UKM dan Pengaruhnya terhadap Kinerja UKM di Surabaya, Jurnal Manajemen dan Kewirausahaan.Vol. 12, No. 1, pp. 42-55, . 2010.

[21] Pearce, J.A. and Robinson Jr. R.B., Strategic Management, Formulation Implementation and Control, Fourth Edition, Richard D. Irwin lnc., Boston., 2005

[22] Cheah, C.Y.J., and J.B. Miller., Empirical Study of Strategic Performance of Global Construction Firms, Journal Construction, Engineering Management, Vol. 130, No. 6, pp. 808-817, 2004.

[23] Peraturan Menteri Pekerjaan Umum Republik Indonesia, Nomor 08/PRT/M/2011 tentang Pembagian Subklasifikasi dan Subkualifikasi Usaha Jasa Konstruksi. 2011.

[24] Dardak, H. Jumlah Tenaga Konstruksi RI yang Bersertifikat Masih Sedikit.http:// economy.okezone. com/read/2014/09/18/471/1040771/jumlah-tenaga-konstruksi-ri-yang-bersertifikat-masih-sedikit (diakses 20 Januari 2015 ), 2014.

[25] Huda, M. dan Wibowo, M.A. Strategies to Increase Performance and Sustainability of Construction Services Company in East Java Indonesia, Journal of Basic and Applied Scientific Research,Vol. 3, No. 6, pp. 741-747, 2013.

\section{AUTHOR PROFILE}

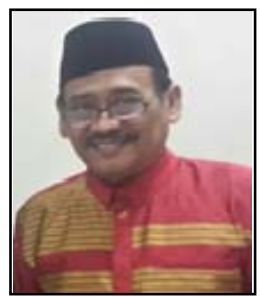

Miftahul Huda, born in Gresik East Java Province, Indonesia. Doctorate Education in Economic (2009) and Doctorate of Civil Engineering (2015). As the Vice Rector of Academic Affairs of Wijaya Kusuma University Surabaya-Indonesia (2004-2008). As head of various construction projects such as toll roads, bridges, high rise buildings, ports and government buildings (1986-2017). As Chairman of the professional association of Indonesian Construction Experts (2012-2017). As the founder and expert of Wekateks Consultant and Wekateks Consuindo (general contractor). 